\title{
An antimicrobial effect associated with rabbit primary aqueous humour
}

University of Bristol

Department of Ophthalmology J P Diamond D L Easty

Department of Microbiology J P Leeming A D Smart

A J Hedges

Department of Veterinary Medicine P Duffus

Correspondence to: Mr J P Diamond, University of Bristol Department of Ophthalmology, Bristol Eye Hospital, Lower Maudlin Street, Bristol BS2 2LX. Accepted for publication 27 August 1993

\author{
J P Diamond, J P Leeming, A D Smart, P Duffus, A J Hedges, D L Easty
}

\begin{abstract}
Viability curves were recorded for a variety of bacteria suspended in rabbit primary aqueous humour. Controls included neat rabbit serum, dilute rabbit serum $(1 / 50)$, dilute heat treated fetal bovine serum (1/50), and balanced salt solution. Rabbit aqueous humour was bactericidal in vitro for Staphylococcus aureus and Pseudomonas aeruginosa. Micrococcus spp, Streptococcus pneumoniae and Escherichia coli were not affected. The factor mediating the bactericidal effect survives filtration $(0.2 \mu \mathrm{m}$ porosity) and freezing in liquid nitrogen $\left(-196^{\circ} \mathrm{C}\right)$ but is labile when stored in air at temperatures of $4^{\circ} \mathrm{C}, 25^{\circ} \mathrm{C}$, and $37^{\circ} \mathrm{C}$ for 1 hour. The bactericidal effect was stable when aqueous humour was stored in an atmosphere of $5 \% \mathrm{CO}_{2}$ at $37^{\circ} \mathrm{C}$ for 3 hours. The antibacterial component in rabbit aqueous humour has yet to be identified.

(Brf Ophthalmol 1994; 78: 142-148)
\end{abstract}

Cataract surgery has a low postoperative infection rate. Published incidences range from $0.022 \%$ to $1 \cdot 42 \%,{ }^{12}$ averaging $0.67 \%$ - well below the $7 \cdot 5 \%$ incidence seen in other surgical sciences. ${ }^{3}$

These figures have been thought to confirm the superiority of ophthalmic antimicrobial surgical technique. ${ }^{4}$ This proposal is countered, however, by Vafidis ${ }^{5}$ who demonstrated bacterial contamination of $26 \%$ of intraocular lenses inserted into 50 eyes during extracapsular cataract extraction (ECCE), and by Sherwood ${ }^{6}$ who demonstrated contamination of $29 \%$ of anterior chamber aspirates taken from 101 eyes undergoing ECCE. Dickey ${ }^{7}$ took aspirates from the anterior chambers of 30 patients undergoing uncomplicated ECCE and found $43 \%$ to be culture positive. That none of these eyes developed endophthalmitis was considered due to the inoculum being of small size and of low virulence.

In vivo animal work, however, suggests that the eye has innate resistance to bacterial infection. Meredith ${ }^{8}$ demonstrated rapid sterilisation 3 days after intravitreal injection of between 5000 and 10000 Staphylococcus epidermidis cells into rabbit eyes (which had previously undergone lens removal), while Davey ${ }^{9}$ compared the growth of Klebsiella pneumoniae in the vitreous cavity of normal rabbit eyes with that in subcutaneous croton oil pouches (artificial oil reservoirs). The vitreous exhibited rapid sterilisation, while the organisms within the oil pouches continued to multiply over a 5 day period.

Beyer $^{10}$ inoculated Staphylococcus aureus into the anterior chamber of monkey eyes following lens extraction. Where the posterior lens capsule formed an intact barrier between aqueous and vitreous, 10000 organisms were eradicated. In the absence of this barrier an endophthalmitis occurred following a much smaller infectious load. Shockley et $a l^{11}$ performed a similar experiment using rabbit eyes and Pseudomonas aeruginosa: where the posterior lens capsule was intact the anterior chamber could eradicate an infectious load 20 times greater than that which induced endophthalmitis when inoculated into the vitreous.

Maylath and Leopold ${ }^{12}$ inoculated Staphylococcus aureus into normal rabbit eyes: after introducing 700 organisms into the vitreous cavity endophthalmitis rapidly ensued, while the corneal stroma eradicated this number; in contrast, the anterior chamber could eradicate 5000 organisms. He concluded that the eye possessed an effective antimicrobial defence that was most efficient in the anterior chamber. The high ratio of culture positive vitreous to aqueous taps in known cases of endophthalmitis ${ }^{101314}$ may be a reflection of these findings.

Various hypotheses could explain an innate protection against bacterial infection possessed by the anterior chamber: (1) that aqueous humour is nutritionally inadequate to support the growth of bacterial organisms; (2) that invading micro-organisms are eluted from the anterior chamber with the bulk flow of aqueous humour via the trabecular meshwork; (3) that aqueous humour contains significant amounts of lysozyme, lactoferrin, transferrin, complement, immunoglobulin, opsonins, or other, as yet unrecognised antibacterial factor(s); and (4) a combination of some, or all of these factors.

This project has been designed to investigate the presence and nature of antibacterial factors within rabbit primary aqueous humour.

\section{Materials and methods}

AQUEOUS HUMOUR

Aqueous humour was collected from adult New Zealand White rabbits of both sexes, weighing between 2 and $2.5 \mathrm{~kg}$. The rabbits were bred for domestic consumption and slaughtered by cutting the major vessels in the neck. A volume of 50-75 $\mu \mathrm{l}$ of aqueous humour was collected immediately after death via a 27 gauge needle inserted at the corneal limbus, snap frozen in liquid nitrogen and stored at $-70^{\circ} \mathrm{C}$. Before each experiment, individual samples of aqueous humour were thawed and pooled.

Aqueous humour was collected from batches of approximately 70 animals exposed to similar conditions before slaughter. A small amount of aqueous humour was collected from rabbits bred 
for research purposes under controlled conditions.

ORGANISMS

The organisms used in this study included laboratory strains of Staphylococcus aureus, National Collection of Type Culture (NCTC) number 6571, Pseudomonas aeruginosa (NCTC 10662), Escherichia coli (NCTC 10418), Staphylococcus epidermidis (NCTC 4276), and clinical isolates of Streptococcus pneumoniae and Micrococcus spp.

\section{BACTERIAL PREPARATION}

A volume of $100 \mu \mathrm{l}$ of an overnight broth was inoculated into $10 \mathrm{ml}$ of brain/heart infusion broth (Oxoid, Basingstoke, UK) and incubated at $37^{\circ} \mathrm{C}$. After 2 hours the organisms were spun, washed twice in phosphate buffered saline (PBS, Sigma Chemical Co, Poole, UK), re-spun, and suspended in PBS to give a final count of approximately $10^{6}$ colony forming units $/ \mathrm{ml}$ (CFU/ml).

\section{BACTERIAL KILLING CURVES}

A volume of $100 \mu \mathrm{l}$ of bacterial suspension was inoculated into $900 \mu$ l of rabbit aqueous humour and incubated at $37^{\circ} \mathrm{C}$ in $12 \mathrm{~mm}$ diameter glass test tubes with loose fitting caps. At intervals, $100 \mu \mathrm{l}$ of culture were removed and serially diluted into PBS. Viable bacterial counts were recorded on DST agar (Oxoid, Basingstoke, UK) using either the Spiral System (Spiral Systems, Cincinnati, $\mathrm{OH}$ ) or the method of Miles et $a l .{ }^{15}$ Control killing curves were obtained by simultaneous inoculation of organisms into balanced salt solution (BSS, Alcon Laboratories, Watford, UK) whole rabbit serum (Sigma Chemical Co, Poole, UK), dilute rabbit serum (1/50 rabbit serum/BSS), and heat treated, dilute fetal bovine serum $\left(56^{\circ} \mathrm{C}\right.$ for 30 minutes of $1 / 50$ fetal bovine serum/BSS) (Sigma Chemical Co, Poole, UK).

\section{SIZE OF BACTERIAL AGGREGATES}

Standard killing curves were initiated as above using filtered (Acrodisc $0.2 \mu \mathrm{m}$ low protein binding filter, Gelman Sciences, Ann Arbor, MI, USA) rabbit aqueous humour, and BSS. At intervals, $1 \mathrm{ml}$ cultures were fixed for 1 hour using $20 \mu \mathrm{l}$ of $20 \%$ glutaraldehyde in aqueous solution (Sigma Chemical Co, Poole, UK). Cultures were then mixed with $25 \mathrm{ml}$ of filtered $(0.22 \mu \mathrm{m}) \mathrm{PBS}$ and particle size recorded using a $50 \mu \mathrm{m}$ aperture on a Coulter Counter ZM (Coulter Electronics Ltd, Luton, UK).

\section{LONGEVITY OF THE BACTERICIDAL EFFECT}

Standard killing curves were initiated as above. After 3 hours the aqueous humour/bacterial suspension was spun and the organisms resuspended in freshly thawed aqueous humour. humour were subjected to a variety of pretreatments to investigate the stability of the antibacterial effect.

\section{Effect of refreezing}

The aqueous humour was snap frozen for a second time in liquid nitrogen $\left(-196^{\circ} \mathrm{C}\right)$ before bacterial inoculation.

\section{Effect of temperature}

The aqueous humour was stored in air at different temperatures for 30-60 minutes before bacterial inoculation.

\section{Effect of filtration}

The aqueous humour was passed through $0 \cdot 2$ $\mu \mathrm{m}$ filters (Acrodisc $0.2 \mu \mathrm{m}$ low protein binding filter, Gelman Science, Ann Arbor, MI, USA and $0.2 \mu \mathrm{m}$ Minisart, Sartorius $\mathrm{GmbH}$, Gottingen, German) before inoculation.

\section{Effect of dilution}

The aqueous humour was serially diluted with balanced salt solution before inoculation.

Effect of an atmosphere of $5 \% \mathrm{CO}_{2}$

The aqueous humour was exposed to an atmosphere of $5 \% \mathrm{CO}_{2}$ at $37^{\circ} \mathrm{C}$ for 3 hours before inoculation.

\section{AQUEOUS HUMOUR ANALYSIS}

Aqueous humour proteins were separated by electrophoresis in $1.5 \mathrm{~mm}$ thick, $10 \%$ polyacrylamide gels in the presence of sodium dodecyl sulphate (SDS-PAGE) in a 'Mini-protean II' cell (Bio-rad Laboratories Ltd, Hemel Hempstead). Specimens containing approximately $0.02 \mathrm{mg}$ protein were mixed (1:1) with Laemmli's sample buffer $^{16}$ and run under reducing conditions. Commercial molecular weight standards (Sigma Chemical Co, Poole, UK) were used. SDSPAGE gels were fixed and stained in $0.25 \%$ Coomassie blue, $40 \%$ methanol, $10 \%$ acetic acid for 1 hour, then destained in three changes of $40 \%$ methanol, $10 \%$ acetic acid.

Total aqueous humour protein was measured using the method described by Johnson and Lott. ${ }^{17}$ The electrolytic profile of aqueous humour was analysed using the Hitachi 717 random access analyser (Hitachi, Boehringer Mannheim, Germany).

The polymorphonuclear cell content of the aqueous humour was analysed using light microscopy after centrifugation of $2 \mathrm{ml}$ at $2000 \mathrm{rpm}$ for 10 minutes.

\section{STATISTICAL ANALYSIS}

Statistical analyses were carried out on the logarithms of the viable counts. When replicate determinations were available, a straightforward two way analysis of variance allowed direct determination of experimental error. In these instances, orthogonal comparisons between 
treatments were made by means of Fisher's $F$ or Student's $t$ tests.

For experiments without replicate determinations at each sampling point (for example, the Pseudomonas aeruginosa data), the following method was used. A regression analysis of variance was performed on the linear (growth) region of the graph. The residual variance extracted from this analysis was then used as an estimate of average experimental error which was applied to each sampling point. Scheffé's statistic was used to determine statistical significance.

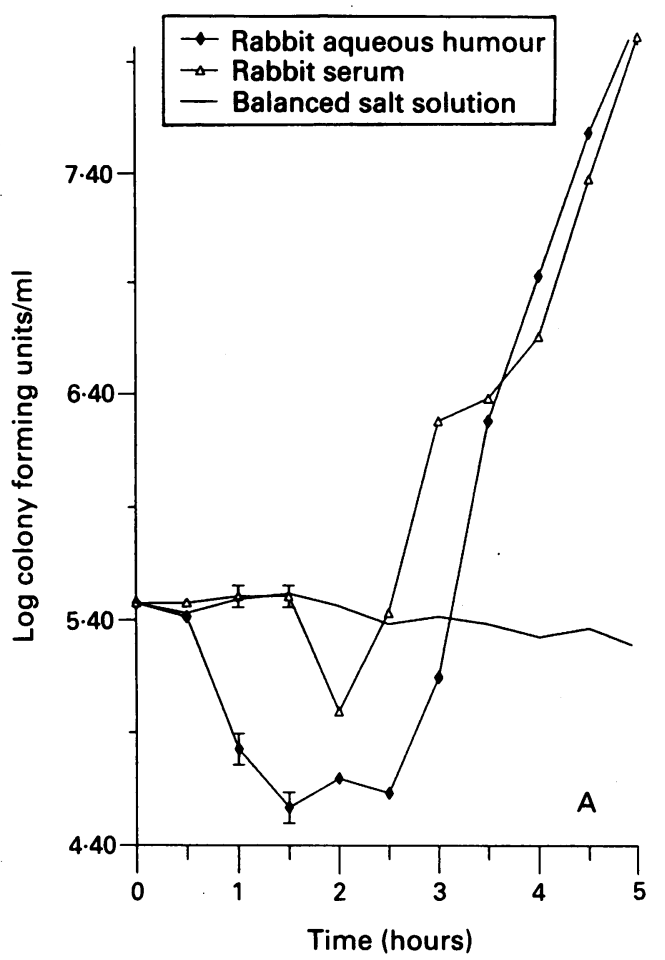

curves for Staphylococcus aureus NCTC No 6571

suspended in rabbit aqueous humour $(R A H)$, rabbit serum $(R S)$, and balanced salt solution (BSS). The difference between $R A H$ and $R S$ is significant between 1 and 2 hours $(p<0.001$, analysis of variance, single tailed Student's t test, $d f=4$ ). Error bars show standard error of the mean. (B) Viability curves for Staphylococcus aureus NCTC No 6571 suspended in rabbit aqueous humour and $1 / 50$ dilutions (into BSS) of rabbit serum and heat inactivated fetal bovine serum. (C) Viability curves for Pseudomonas aeruginosa NCTC No 10662 suspended in $R A H$, $R S$, and BSS. The difference between $R A H$ and $B S S$ is significant between 0.5 and 1.5 hours $(p<0.01$, analysis of variance with Scheffe's method for general comparison of means). Error bars show standard error of the mean. (D) Viability curves for Staphylococcus epidermidis NCTC No 4276 suspended in $R A H$, $R S$, and $B S S$.

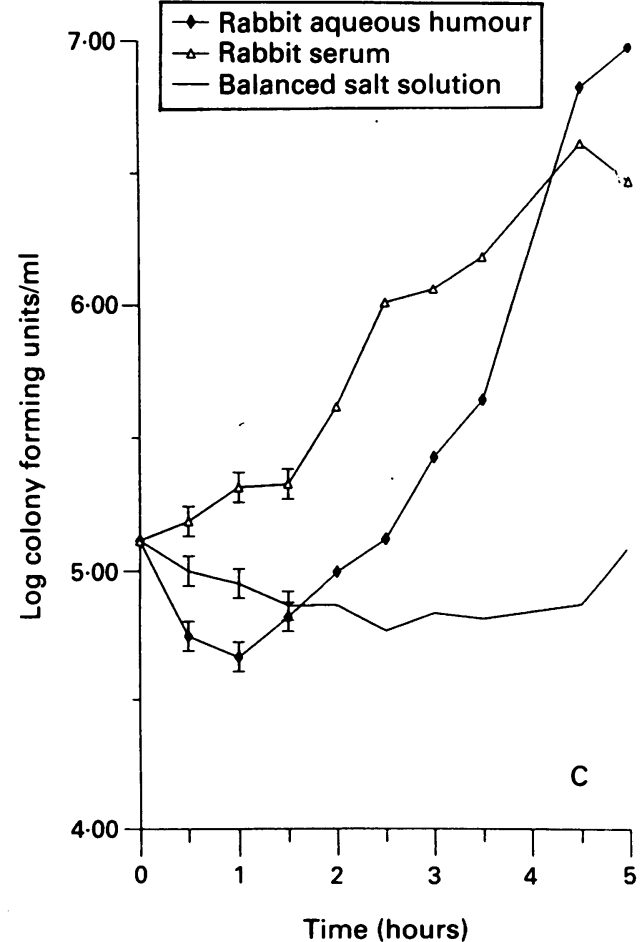

\section{Results}

ANTIBACTERIAL ACTIVITY

There was a reduction in viable colony count for Staphylococcus aureus and Pseudomonas aeruginosa cultured in rabbit aqueous humour compared with the controls (Fig 1A, 1B, and 1C). The reduction in colony numbers (CFU/ml) of Staphylococcus aureus was significant between 60 and 90 minutes $(p<0 \cdot 001$, analysis of variance, single tailed Student's $t$ test, $\mathrm{df}=4$ ). For Pseudomonas aeruginosa the difference was

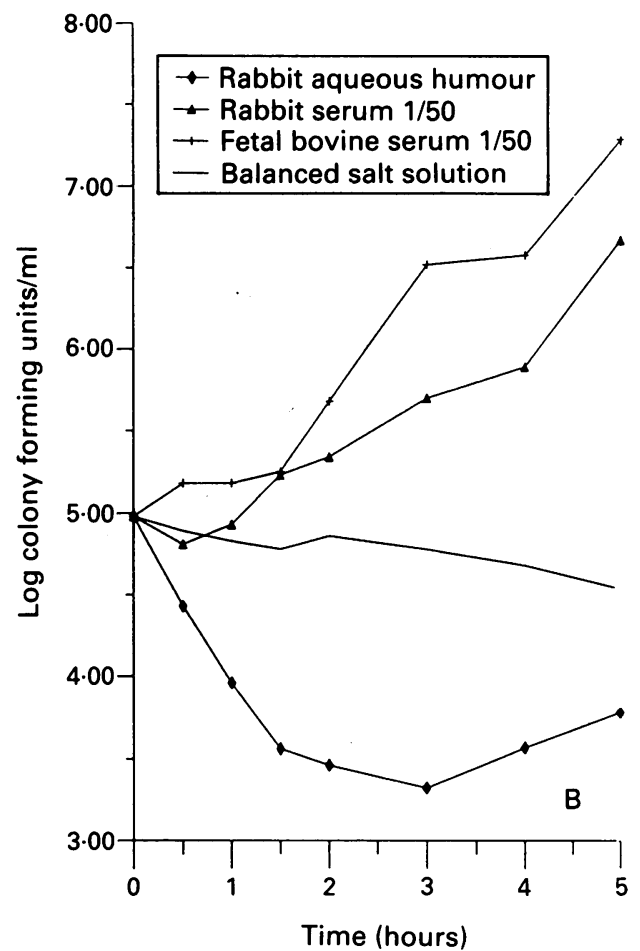


Figure 2 Particle (CFU) volume of Staphylococcus aureus NCTC No 6571 cultured for 90 minutes in rabbit aqueous humour and balanced salt solution and then fixed with $20 \%$ glutaraldehyde before measurement using a $50 \mathrm{um}$ aperture on a Coulter counter $Z M$.

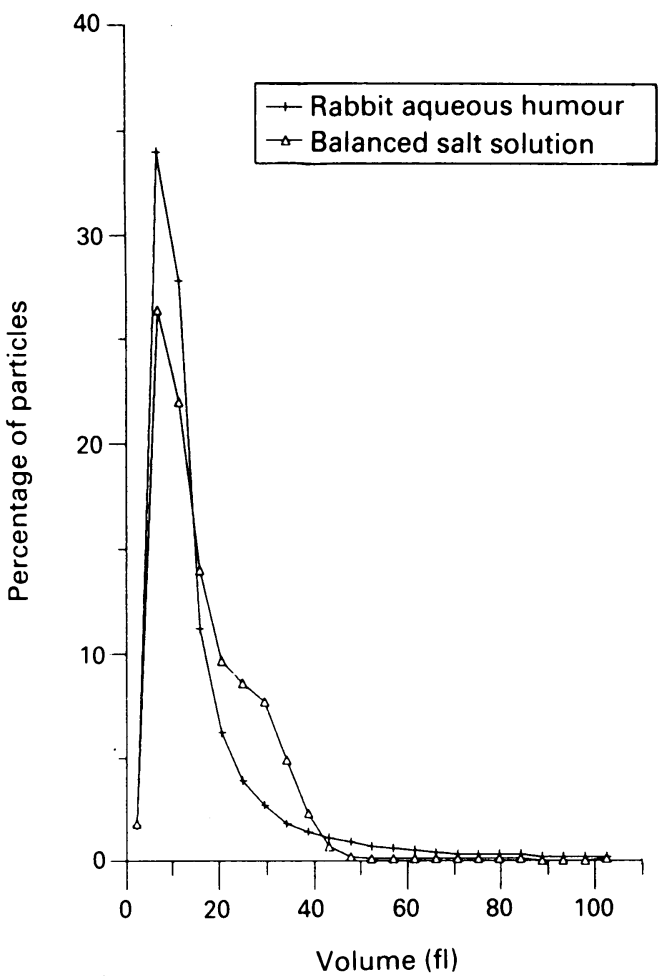

significant between 30 and 90 minutes $(\mathrm{p}<0.01$, analysis of variance with Scheffé's method for general comparison of means). There was no antibacterial effect mediated by aqueous humour upon Micrococcus spp, Escherichia coli, or Streptococcus pneumoniae. After an initial decline, Staphylococcus epidermidis grew better in aqueous humour than in the controls (Fig 1D).

\section{CONSISTENCY OF EFFECT}

Although there was some variability in potency and duration of antibacterial effect between different batches of aqueous humour, there was

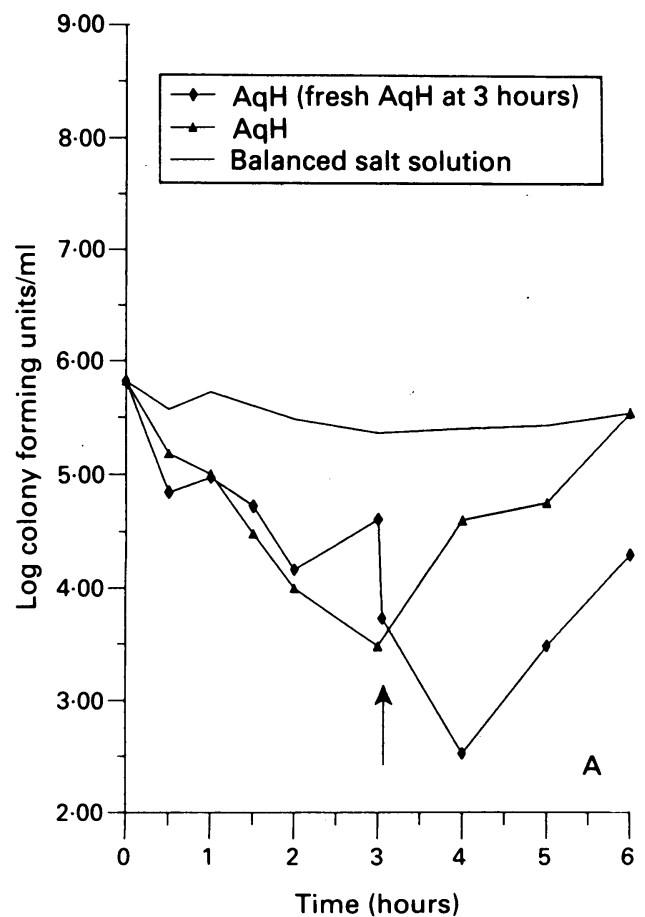

minimal intrabatch variation between samples. The effect was also present in animals bred for research.

\section{BACTERIAL PARTICLE SIZE}

Figure 2 illustrates particle size for Staphylococcus aureus cultured for $\mathbf{9 0}$ minutes in aqueous humour and BSS. There was minimal difference between the two groups indicating that the observed reduction in colony forming units was not due to bacterial aggregation.

\section{LONGEVITY OF THE BACTERICIDAL EFFECT}

Figure 3A shows a repeated bactericidal effect caused by replacing the aqueous humour after 3 hours.

\section{STABILITY OF THE BACTERICIDAL EFFECT}

Figure 3B shows the effect of incubation at various temperatures upon aqueous humour before bacterial inoculation. Storing aqueous humour for 1 hour at temperatures between 4 and $37^{\circ} \mathrm{C}$ abrogated the effect. The effect was also destroyed after 30 minutes at $56^{\circ} \mathrm{C}$. The effect would survive filtration through an Acrodisc $0.2 \mu \mathrm{m}$ low protein binding filter but was lost after passing through a Minisart cellulose acetate $0.2 \mu \mathrm{m}$ filter (Fig 4A and 4B). The effect survived repeat freezing in liquid nitrogen but was progressively reduced after serial dilution into BSS (Fig 4C).

The effect could be maintained over longer periods by storing the aqueous humour at $37^{\circ} \mathrm{C}$ in $5 \% \mathrm{CO}_{2}$ (Fig 4D). The difference between the killing curves for aqueous humour stored in air and $5 \% \mathrm{CO}_{2}$ was significant between 2 and $2 \cdot 5$ hours ( $p<0 \cdot 001$, analysis of variance). A $5 \% \mathrm{CO}_{2}$ atmosphere acts to buffer the aqueous humour $\mathrm{pH}$ (Fig 5) which may be the mechanism by

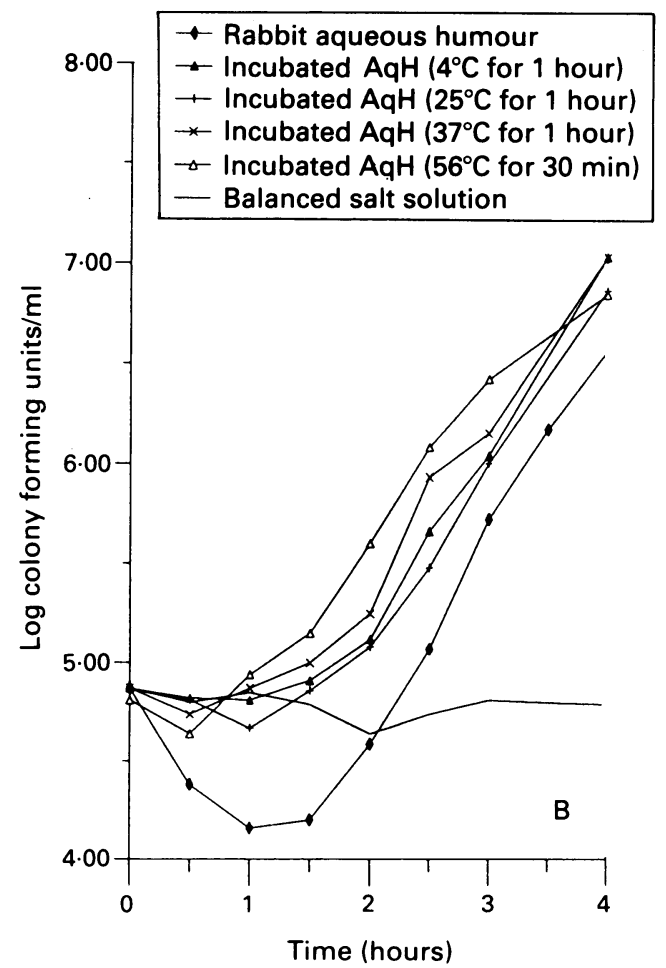

Figure 3 (A) Viability curves for Staphylococcus aureus NCTC No 657l suspended in rabbit aqueous humour. After 3 hours (arrow) the suspension was spun and the organisms transferred into freshly thawed aqueous humour. (B) Viability curves for Staphylococcus aureus NCTC No 6571 suspended in rabbit aqueous humour ( $A q H)$ pretreated by storage at different temperatures for 30 minutes or 1 hour. 
which the antibacterial effect is maintained over the longer term.

AQUEOUS HUMOUR ANALYSIS

There were no differences evident in SPS-PAGE profiles of samples of aqueous humour which did and did not mediate the antibacterial effect. Table 1 illustrates the electrolyte and protein content of those same samples. No appreciable differences were observed between the samples examined. There were no white blood cells identified after aqueous humour centrifugation.

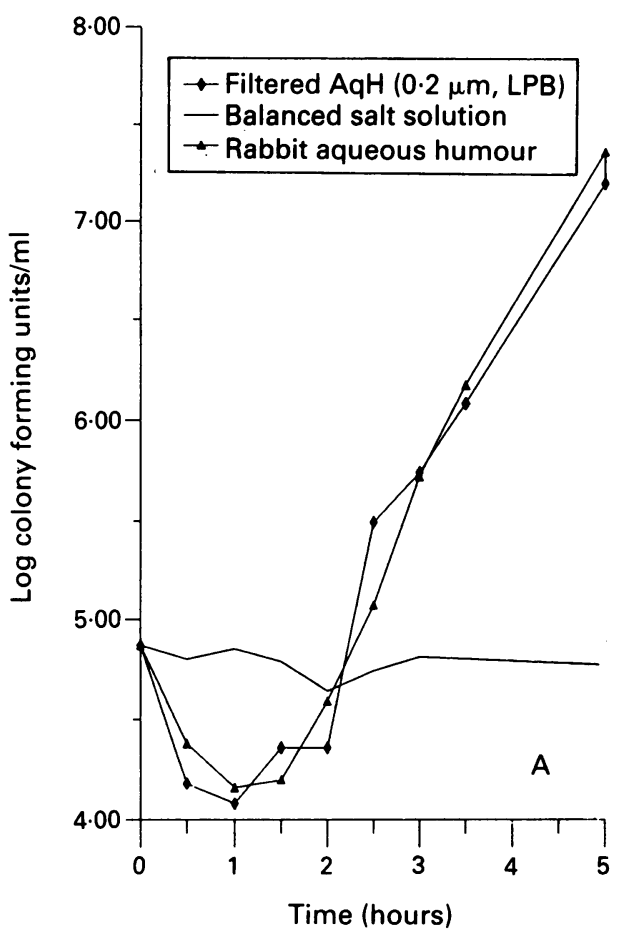

igure 4 (A) Viability curves for Staphylococcus aureus NCTC No 6571 suspended in rabbit aqueous humour ( $A q H)$ filtered via a $0 \cdot 2$ um low protein binding filter (LPB) (Acrodisc $0 \cdot 2$ um low protein binding filter, Gelman Sciences, Ann Arbor, MI). (B) Viability curves for Staphylococcus aureus NCTC No 6571 suspended in rabbit aqueous humour $(\mathrm{AqH})$ filtered via a $0.2 \mu \mathrm{m}$ high protein binding $(H P B)$ filter $(0.2 \mu \mathrm{m}$ Minisart, Sartorius GmbH, Gottingen, Germany). (C) Viability curves for Staphylococcus aureus NCTC No 6571 suspended in rabbit aqueous humour $(A q H)$ pretreated by serial dilution with balanced salt solution $(B S S)$. (D) Viability curves for Staphylococcus aureus NCTC No 6571 suspended in rabbit aqueous humour (AqH) pretreated by storage at $37^{\circ} \mathrm{C}$ for 3 hours in either air or $5 \% \mathrm{CO}_{2}$. The

difference between air and $\mathrm{CO}_{2}$ is significant between 120 and 150 minutes $(p<0.0001$, analysis of variance). Error bars show standard error of the mean.

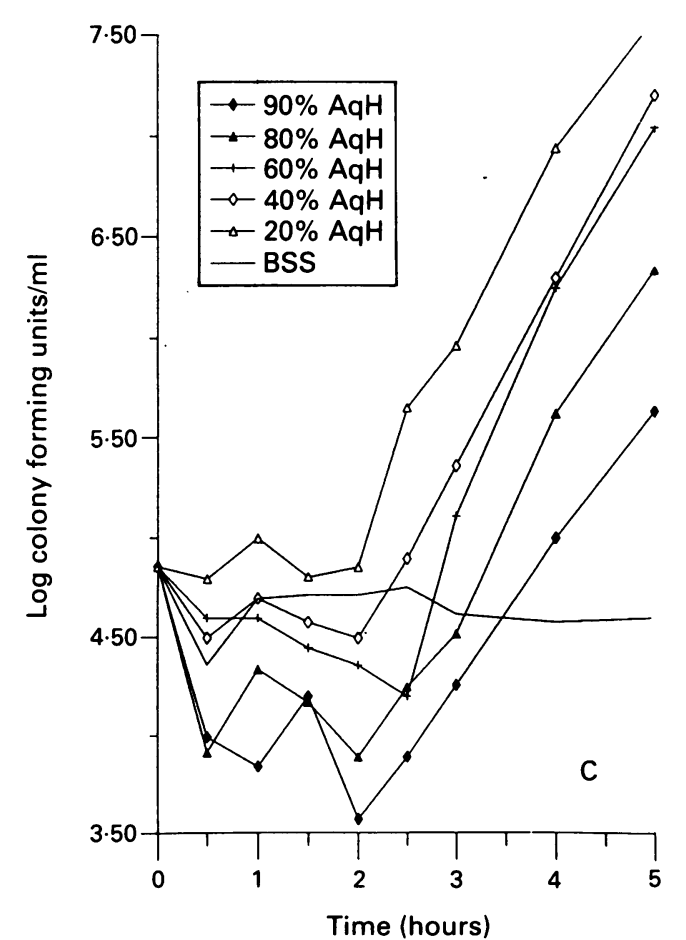

\section{Discussion}

This investigation has demonstrated an approximate $90 \%$ drop in viable colony count for Staphylococcus aureus and Pseudomonas aeruginosa cultured for 2-3 hours in rabbit primary aqueous humour when compared with a range of controls. The controls included whole rabbit serum (containing antibacterial factors including immunoglobulin and complement), dilute rabbit serum (containing a total protein concentration closer to that of the aqueous humour), dilute heat treated fetal bovine serum (containing a similar amount of protein to
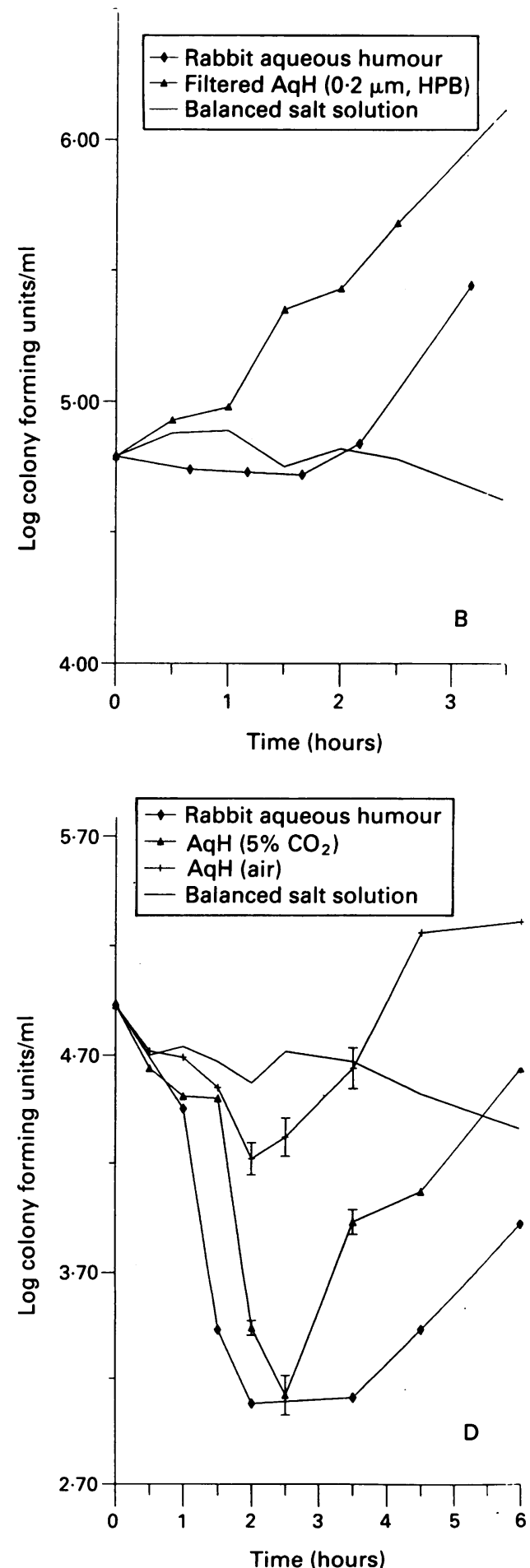
Figure 5 pH of rabbit aqueous humour $(A q H)$ stored at $37^{\circ} \mathrm{C}$ in air and $5 \%$ $\mathrm{CO}_{2}$

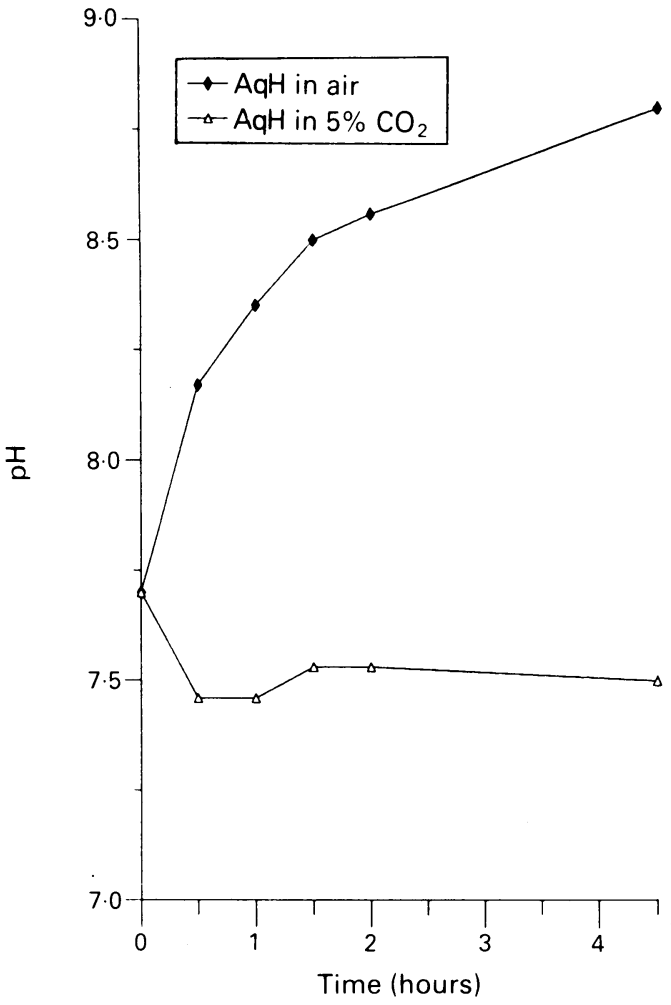

aqueous humour, but minimal immunoglobulin and no complement), and balanced salt solution - an approximation to protein free aqueous humour.

The quantitative techniques applied count the number of viable colony forming units (CFU) per unit volume. These methods cannot differentiate between bacterial destruction and bacterial aggregation because clumps of bacteria give rise to single colonies. To exclude the latter as the cause for the decline in CFUs a Coulter counter was used to measure cell volume. For bacterial aggregation to explain the $90 \%$ reduction seen in bacterial units, the mean particle volume for organisms cultured in aqueous humour would have to be approximately 10 times that for the control group (BSS). There was no such difference shown, demonstrating that the reduction in CFU count may be apportioned to bacterial destruction.

Rabbit primary aqueous humour was bactericidal in vitro for Staphylococcus aureus and Pseudomonas aeruginosa. It was not bactericidal for Micrococcus spp, Escherichia coli, or Streptococcus pneumoniae. After an initial decline in numbers, Staphylococcus epidermidis grew better in aqueous humour than in the controls. It is interesting to note that Staphylococcus epidermidis

Table 1 Electrolytic constitution and protein content of bactericidal factor positive and negative samples of rabbit aqueous humour

\begin{tabular}{lccc}
\hline Sample & 1 & 2 & 3 \\
\hline Bactericidal & Yes & No & Yes \\
Lactate $(\mathrm{mM} / \mathrm{l})$ & $10 \cdot 5$ & $10 \cdot 3$ & $10 \cdot 0$ \\
Glucose $(\mathrm{mg} / \mathrm{dl})$ & $5 \cdot 3$ & $5 \cdot 3$ & $5 \cdot 2$ \\
Urea $(\mathrm{mM} / \mathrm{l})$ & $<0 \cdot 5$ & $<0 \cdot 5$ & $<0 \cdot 5$ \\
$\mathrm{Na}(\mathrm{mM} / \mathrm{l})$ & 147 & 146 & 143 \\
$\mathrm{~K}(\mathrm{mM} / \mathrm{l})$ & $4 \cdot 9$ & $4 \cdot 9$ & $4 \cdot 7$ \\
$\mathrm{Cl}(\mathrm{mM} / \mathrm{l})$ & 105 & 106 & 103 \\
$\mathrm{HCO}(\mathrm{mM} / \mathrm{l})$ & 27 & 28 & 26 \\
Total protein $(\mathrm{mg} / 100 \mathrm{ml})$ & 115 & 98 & 104 \\
\hline
\end{tabular}

is the commonest cause of postoperative endophthalmitis. ${ }^{18}$

The killing curves demonstrated a drop in bacterial count extending between 2 and 3 hours following bacterial inoculation. After this period the bacterial counts recovered and entered a period of logarithmic increase. Bacterial growth recovers either because the mediator of the antibacterial effect is exhausted or because it is unstable but not because the organisms develop resistance to its effect.

There was interbatch variation in the potency of the antibacterial effect between different groups of rabbits (but minimal intrabatch variation). Different aqueous humour samples retained potency for periods of between 90 and 180 minutes after inoculation. A small number of samples did not demonstrate any bacterial killing. There was, however, no apparent difference in aqueous humour total protein content, electrolytic protein profile (SDS-PAGE), or electrolyte constitution between samples of aqueous humour which mediated and did not mediate the effect.

The total protein content of the 'primary' aqueous humour collected from farmed animals (approximately $100 \mathrm{mg} / 100 \mathrm{ml}$ ) is higher than the expected figure of 12.4 (SD 2.00$) \mathrm{mg} / 100 \mathrm{ml}$ protein. ${ }^{19}$ This elevated protein level allied to the variability in the presence and potency of the antibacterial effect may reflect differences in the conditions under which these farm animals were kept before slaughter. Although it is possible that the farmed animals were given dietary supplements or antibiotics which could influence aqueous humour constitution, the bactericidal effect was also demonstrated in laboratory bred rabbits kept under controlled conditions.

The factor survived filtration through a 0.2 $\mu \mathrm{m}$ low protein binding filter but was lost after filtration through a Minisart $0 \cdot 2 \mu \mathrm{m}$ filter. It survived refreezing in liquid nitrogen but was labile when stored in air at temperatures of 4,25 , and $37^{\circ} \mathrm{C}$ for 1 hour. The effect was stable when the aqueous humour was stored in an atmosphere of $5 \% \mathrm{CO}_{2}$ at $37^{\circ} \mathrm{C}$. Although storage in $5 \%$ $\mathrm{CO}_{2}$ buffered the $\mathrm{pH}$ of the aqueous humour it is not clear whether this influence was important in maintaining the antibacterial effect.

Primary rabbit aqueous humour contains $2 \cdot 0$ $\mathrm{mg} / 100 \mathrm{ml}$ of $\operatorname{IgG}^{20}$ but no $\operatorname{IgD}, \operatorname{IgA}$, or $\operatorname{IgM} .^{21}$ Primary aqueous also contains complement fractions $\mathrm{Cl}, \mathrm{C} 3, \mathrm{C} 4$, and $\mathrm{C} 5$ in aqueous/serum ratios ranging from $1 / 1415$ to $1 / 6713 .{ }^{20}$ These levels will probably be too small to significantly affect invading bacteria. Furthermore, immunoglobulin would be expected to withstand the pretreatment regimens which removed the antibacterial effect from aqueous humour and complement should withstand 60 minutes at $4^{\circ} \mathrm{C}$.

Lactoferrin and transferrin are bacteriostatic proteins which limit bacterial replication by binding available iron..$^{22}$ The presence of these compounds would be unlikely to explain the bactericidal effect demonstrated. Although lysozyme is bactericidal, it is more active against Micrococcus spp than against Staphylococcus spp $^{23}$ which is not consistent with the spectrum of activity observed in this investigation. 
It is interesting to speculate on the possible nature of the factor(s) present in rabbit aqueous humour. There has been interest generated recently by the discovery that a group of small antibacterial proteins originally isolated in insects are also present in mammals. ${ }^{24}$ One group, the defensins, have been isolated in humans. ${ }^{24}$ It is feasible that aqueous humour contains a defensin, or defensin-like compound capable of inhibiting prokaryotic cell replication.

Aqueous humour protein has been thought to be derived from the plasma, entering the anterior chamber via selective leakage through vessels of the ciliary body and iris. ${ }^{25}$ Identification of a subtype of transferrin unique to aqueous humour ${ }^{26}$ and of transforming growth factor beta (TGF- $\beta$ ) production by cells in the iris and ciliary body, via local transcription of $\mathrm{mRNA}^{27}$ suggests that some of the proteins in aqueous humour may be synthesised within the eye. It is conceivable that there may be iris/ciliary body production of this aqueous humour antibacterial agent.

Caution must be exercised before extrapolating these results to human ocular infection because the immunological responses of different species are frequently at variance. However, when the rabbit aqueous humour antibacterial factor has been characterised, further work can be undertaken to determine whether the same effect is present in human aqueous humour. If this were the case, it could be of great significance in the apparent resilience of the eye to infection.

We should like to acknowledge the help of Mrs Esther Grinfeld Dr Valerie Smith, and Dr John Armitage in the Department of Ophthalmology, and Dr David Stansbie in the Department of Biochemistry, Bristol Royal Infirmary.

1 Jenkins CDG, McDonnell PJ, Spalton DJ. Randomised single blind trial to compare the toxicity of subconjunctival gentamicin and cefuroxime in cataract surgery. Brf Ophthalmol 1990; 74: 734-8.

2 Meyers-Elliott RH, Dethlefs BA. Experimental Klebsiella induced endophthalmitis in the rabbit. Arch Ophthalmol 1982; 100: 1959-63.

3 Bröte L, Gillquist J, Tärnvik A. Wound infections in general surgery. Acta Chir Scand 1976; 142: 99-106.
4 Burns RP. Postoperative infections in an ophthalmic hospital. Am 7 Ophthalmol 1959; 48: 519-26.

5 Vafidis GC, Marsh RJ, Stacey AR. Bacterial contamination of intraocular lens surgery. Br fOphthalmol 1984; 68: 520-3.

6 Sherwood DR, Rich WJ, Jacob JS, Hart RJ, Fairchild YL. Bacterial contamination of intraocular and extraocular fluids during extracapsular cataract extraction. Eye 1989; 3: 30812.

7 Dickey JB, Thompson KD, Jay WM. Anterior chamber aspirate cultures after uncomplicated cataract surgery. $A m \mathcal{F}$ Ophthalmol 1991; 112: 278-82.

8 Meredith TA, Trabelsi A, Miller MJ, Aguilar E, Wilson LA. Spontaneous sterilization of experimental Staphylococcus epidermidis endophthalmitis. Invest Ophthalmol Vis Sci 1990; 31 : $181-6$.

9 Davey P, Barza M, Peckman C. Spontaneous inhibition of bacterial growth in experimental gram-negative endophthalmitis. Invest Ophthalmol Vis Sci 1987; 28: 867-73.

10 Beyer TL, Volger G, Sharma D, O'Donnell FE. Protective barrier effect of the posterior lens capsule in exogenous bacterial endophthalmitis - an experimental primate study. Invest Ophthalmol Vis Sci 1984; 25: 108-12.

11 Shockley RK, Jay WM, Fishman PH, Aziz MZ, Rissing JP. Effect of inoculum size on the induction of endophthalmitis in aphakic rabbit eyes. Acta Ophthalmol 1985; 63: 35-8.

12 Maylath FR, Leopold IH. Study of experimental intraocular infection. Am f Ophthalmol 1955; 40: 86-101.

13 Bodé DD, Gelender H, Forster RK. A retrospective review of endophthalmitis due to coagulase-negative staphylococci. BrF Ophthalmol 1985; 69: 915-9.

14 Forster RK, Zachary IG, Cottingham AJ, Norton EWD. Further observations on the diagnosis, cause and treatmen of endophthalmitis. Am $\mathcal{F}$ Ophthalmol 1976; 81: 52-6.

15 Miles AA, Misra SS, Irwin JD. The estimation of the bactericidal power of the blood. $\mathcal{f}$ Hygiene $1938 ; 38$ : 732-49.

16 Laemmli UK. Cleavage of structural proteins during the assembly of the head of bacteriophage T4. Nature $1970 ; 227$ : 680.

17 Johnson A, Lott JA. Standardization of the Coomassie blue method for cerebrospinal fluid proteins. Clin Chem 1978; 24: 1931-3.

18 Heaven CJ, Mann PJ, Boase DL. Endophthalmitis following cataract surgery: a review of 32 cases. Brf Ophthalmol 1992; 76: 419-23.

19 Tripathi RC, Millard CB, Tripathi BJ. Protein composition of human aqueous humour: SDS-PAGE analysis of surgical and post-mortem samples. Exp Eye Res 1989; 48: 117-30.

20 Mondino BJ, Rao MS. Haemolytic complement activity in aqueous humour. Arch Ophthalmol 1983; 101: 465-8.

21 Sen DK, Sarin GS, Saha K. Immunoglobulins in human aqueous humour. Br 7 Ophthalmol 1977; 61: 216-7.

22 Griffiths E, Bullen JJ. In: Bullen JJ, Griffiths E, eds. Iron and infection: molecular, physiological and clinical aspects. infection: molecular, physiological and

23 Schleifer KH, Kloos WE. Isolation and characterisation of staphylococci from human skin. Int $\mathcal{F}$ Syst Bacteriol 1975; 25: $50-61$.

24 Kimbrell DA. Insect antibacterial proteins: not just for insects and against bacteria. Bioessays 1991; 13: 657-63.

25 Maurice DM. Protein dynamics in the eye studied with labelled proteins. Am F Ophthalmol 1959; 47: 361-7.

26 Tai-Chin YU, Okamura R. Quantitative study of characteristic aqueous humour transferrin, serum transferrin and desialized serum transferrin in aqueous humour. $f_{p n} f$ Ophthalmol 1988; 32: 268-74.

27 Knisely TL, Bleicher PA, Vibbard CA, Granstein RD Production of latent transforming growth factor-beta and Production of latent transforming growth factor-beta and
other inhibitory factors by cultured murine iris and ciliary body cells. Curr Eye Res 1991; 10: 761-71. 